\title{
Chitinilyticum litopenaei sp. nov., isolated from a freshwater shrimp pond, and emended description of the genus Chitinilyticum
}

\author{
Shu-Chen Chang, ${ }^{1,2} \dagger$ Ming-Chang $\mathrm{Wu}^{2}{ }^{2}$ Wen-Ming Chen, ${ }^{3} \dagger$ \\ Yung-Hsing Tsai $^{3}$ and Tsong-Ming Lee ${ }^{4}$ \\ ${ }^{1}$ Department of Hospitality Management, Tajen University, Pingtung, Taiwan, ROC \\ ${ }^{2}$ Department of Food Science, National Pingtung University of Science and Technology, Pingtung, \\ Taiwan, ROC \\ ${ }^{3}$ Department of Seafood Science, National Kaohsiung Marine University, Kaohsiung, Taiwan, ROC \\ ${ }^{4}$ Department of Food Science and Technology, Tajen University, Pingtung, Taiwan, ROC
}

Correspondence

Shu-Chen Chang

doris@mail.tajen.edu.tw

\begin{abstract}
Strain $\mathrm{c1}^{\top}$, originally isolated from surface water of a freshwater pond located in Pingtung (southern Taiwan) used for culture of Pacific white shrimp (Litopenaeus vannamei), was subjected to a polyphasic taxonomic analysis. The strain exhibited strong chitinolytic activity and was able to grow under aerobic and anaerobic conditions by utilizing chitin exclusively as the carbon, nitrogen and energy source. Phylogenetic analysis of the 16S rRNA gene sequence revealed a clear affiliation to the Betaproteobacteria, with the closest relatives being Chitinilyticum aquatile $\mathrm{C} 14^{\top}$ and Chitinibacter tainanensis $\mathrm{S}^{\top}{ }^{\top}$, respectively showing 96.7 and $93.6 \% 16 \mathrm{~S}$ rRNA gene sequence similarity. The predominant fatty acids detected in cells of strain $c 1^{\top}$ were $C_{16: 0}$, $\mathrm{C}_{18: 1} \omega 7 c$ and summed feature $3\left(\mathrm{C}_{16: 1} \omega 7 c\right.$ and/or iso- $\left.\mathrm{C}_{15: 0} 2-\mathrm{OH}\right)$. The $\mathrm{G}+\mathrm{C}$ content of the genomic DNA was $62.2 \pm 1.0$ mol\%. On the basis of phylogenetic analysis, DNA-DNA

hybridization data, physiological and biochemical characteristics and fatty acid compositions, the organism was shown to belong to the genus Chitinilyticum whilst representing a novel species within this genus, for which we propose the name Chitinilyticum litopenaei sp. nov. (type strain $\mathrm{c} 1^{\top}=$ DSM $21440^{\top}=$ BCRC $17609^{\top}$ ).
\end{abstract}

Chitin is a complex molecule of natural polymers that is a common constituent of the shells of crustaceans, cell walls of fungi and certain green algae and exoskeletons of insects and is the second most abundant polysaccharide in nature (after cellulose). Chemically, it is an insoluble homopolymer composed of linear chains of $\beta$-1,4-linked $N$-acetyl- $\beta$-Dglucosamine (GlcNAc) residues, which are highly crosslinked by hydrogen bonds. Chitin and its partially deacetylated derivatives exhibit interesting properties and constitute a valuable raw material for biomedical, agricultural, and cosmetic applications (Shigemasa \& Minami, 1996).

Enormous amounts of chitin are synthesized in the biosphere annually, as much as $10^{10}-10^{11}$ metric tons (Gooday, 1990), but only traces remain in the envir-

†These authors contributed equally to this work.

Abbreviation: GlcNAc, $N$-acetyl- $\beta$-D-glucosamine.

The GenBank/EMBL/DDBJ accession number for the 16S rRNA gene sequence of strain $c 1^{\top}$ is EU682455.

An HPLC profile of products of chitin degradation by strain $c 1^{\top}$ is available as supplementary material with the online version of this paper. onment. Turnover of the polysaccharide is attributed primarily to micro-organisms that degrade chitin, allowing carbon and nitrogen to return to the ecosystem (Gooday, 1990). Therefore, it is anticipated that shrimp-culturing ponds would be a rich source of chitin-degrading bacteria. Shrimp (prawn) farming has contributed significantly to the economy of southern Taiwan. There are many different types of shrimp pond in the Pingtung area of southern Taiwan. Some are close to the coast, but others are deep inland. The pond water ranges from fresh through brackish to seawater. These diverse culture types provide dramatically different ecosystems for micro-organisms to develop.

In our previous studies, two strains of chitin-degrading bacteria, Chitinimonas taiwanensis $\mathrm{cf}^{\mathrm{T}}$ and Chitinilyticum aquatile $\mathrm{C} 14^{\mathrm{T}}$, were isolated from two distinct freshwater ponds of shrimp culture (Chang et al., 2004, 2007). In this study, a water sample was collected from a freshwater pond for Pacific white shrimp (Litopenaeus vannamei) culture located in the countryside of Pingtung. The pond water was approximately $25{ }^{\circ} \mathrm{C}$ and $\mathrm{pH} 7.0$. Chitin-degrading bacteria were enriched from $100 \mathrm{ml}$ sample water amended with $0.5 \%(\mathrm{w} / \mathrm{v})$ autoclaved colloidal chitin. The original 
culture was incubated at $25{ }^{\circ} \mathrm{C}$ with shaking at 125 r.p.m. (orbital shaker, $25 \mathrm{~mm}$ radius; Firstek Company). Colloidal chitin was prepared from commercial chitin (Ohka Chemical) as described by Chang et al. (2004). After 5 days of incubation, the enrichment broth was diluted with sterile distilled water and spread onto chitin basal (CB) medium (Chang et al., 2004). A bacterial strain, showing large clear zones around the colonies due to chitin degradation, was isolated and designated $\mathrm{cl}^{\mathrm{T}}$. The colony morphology of strain $\mathrm{cl}^{\mathrm{T}}$ was clearly different from that of Chitinimonas taiwanensis $\mathrm{cf}^{\mathrm{T}}$ but similar to that of Chitinilyticum aquatile $\mathrm{C} 14^{\mathrm{T}}$ (Chang et al., 2004, 2007).

Bacterial cells of strain $\mathrm{cl}^{\mathrm{T}}$ were observed by phase-contrast microscopy (Leica DM 2000) in the lag, exponential and stationary phases of growth to ascertain their morphology. The motility of cells was examined by the hanging drop method. Flagellum staining was performed using the Spot Test flagella stain (BD Difco). Gram staining was performed using the Gram stain set S (BD Difco) and the Ryu non-staining $\mathrm{KOH}$ method (Powers, 1995). Poly$\beta$-hydroxybutyrate granule accumulation was observed by light microscopy after Sudan black staining.

The $\mathrm{pH}$ range for growth was determined by measuring the $\mathrm{OD}_{595}$ of the culture grown in tryptic soy broth (TSB; BD Difco). The medium was adjusted to $\mathrm{pH} 3-11$ at intervals of $1.0 \mathrm{pH}$ unit by using appropriate biological buffers; glycine $/ \mathrm{HCl}$, sodium citrate $/ \mathrm{Na}_{2} \mathrm{HPO}_{4}$, phosphate buffer and glycine $/ \mathrm{NaOH}$ were respectively used below $\mathrm{pH} 4$ and at $\mathrm{pH} 4.0-8.0,6.0-8.0$ and 9.0-11.0. For determination of the temperature range for growth, cells were incubated in $\mathrm{CB}$ broth at $4,10,15,20,25,30,35,40,45$ and $50{ }^{\circ} \mathrm{C}$ using an orbital water-bath shaker (125 r.p.m.). Tolerance of $\mathrm{NaCl}$ was determined by adjusting the salinity of $\mathrm{CB}$ medium to $0,0.25,0.3,0.5,0.75,1,2$ and $3 \%(\mathrm{w} / \mathrm{v}) \mathrm{NaCl}$. Anaerobic cultivation was performed on $\mathrm{CB}$ and $\mathrm{R} 2 \mathrm{~A}$ medium (BD Difco) under $85 \% \mathrm{~N}_{2}, 5 \% \mathrm{CO}_{2}$ and $10 \% \mathrm{H}_{2}$ in an anaerobic chamber (Forma Scientific) and in the AnaeroGen system (Oxoid). Culture supernatant of strain $\mathrm{cl}^{\mathrm{T}}$ was used to detect chitinolytic production by HPLC with a standard of $\mathrm{N}$-acetylchitooligosaccharides from the monosaccharide to hexasaccharide [(GlcNAc $)_{n}, n=1-6$; Sigma] as described previously (Chang et al., 2004, 2007).

Strain $\mathrm{cl}^{\mathrm{T}}$ formed visible colonies (approx. $1.0-1.5 \mathrm{~mm}$ in diameter) on CB agar after 2 days of incubation at $35^{\circ} \mathrm{C}$. The colonies were cream-white in colour, circular and convex with entire edges. Surrounding the colony, a colourless, clear zone was observed with a diameter extended to more than double the colony size, indicating that chitinolysis was performed by strain $\mathrm{cl}^{\mathrm{T}}$ during growth. With a medium containing only minerals and chitin, strain $\mathrm{cl}^{\mathrm{T}}$ still exhibited a reasonable growth rate under both aerobic and anaerobic conditions, indicating that the organism could use chitin as the sole carbon, nitrogen and energy source for growth. Strain $\mathrm{cl}^{\mathrm{T}}$ could also be grown on nutrient and tryptic soy medium. Strain $\mathrm{cl}^{\mathrm{T}}$ grew at $15-40{ }^{\circ} \mathrm{C}, \mathrm{pH} 7.0-11.0$ and $0-0.75 \%(\mathrm{w} / \mathrm{v})$
$\mathrm{NaCl}$. Optimal growth conditions were approx. $30-35{ }^{\circ} \mathrm{C}$, $\mathrm{pH} 8$ and $0.25 \%(\mathrm{w} / \mathrm{v}) \mathrm{NaCl}$. When the chitinolytic products were examined by HPLC and hydrolysis of fluorogenic substrates, the main products that remained in the culture medium were monosaccharides and disaccharides [GlcNAc and (GlcNAc) ${ }_{2}$ ] (Supplementary Fig. S1, available in IJSEM Online). In this respect, strain $\mathrm{cl}^{\mathrm{T}}$ could be distinguished from Chitinimonas taiwanensis $\mathrm{cf}^{\mathrm{T}}$, which produced chitotriose $\left[(\mathrm{GlcNAc})_{3}\right]$ (Chang et al., 2004), Chitinibacter tainanensis $\mathrm{S1}^{\mathrm{T}}$, which produced GlcNAc (Chern et al., 2004), and Chitinilyticum aquatile $\mathrm{C} 14^{\mathrm{T}}$, which produced disaccharides [(GlcNAc) $)_{2}$ (Chang et al., 2007), as the major products of chitin cleavage.

Extraction of genomic DNA and PCR amplification and sequencing of the $16 \mathrm{~S}$ rRNA gene was carried out as described previously (Chen et al., 2001). Sequence reaction fragments were separated using a DNA sequencer (ABI PRISM 310; Applied Biosystems) and sequence assembly was achieved using the Fragment Assembly System program from the Wisconsin Package 9.1 (GCG, 1995). The nearly complete $16 \mathrm{~S}$ rRNA gene sequence of strain $\mathrm{cl}^{\mathrm{T}}$ was compared with corresponding sequences taken from the GenBank, Ribosomal Database Project II and EzTaxon (Chun et al., 2007) databases. Multiple sequence alignment including strain $\mathrm{Cl}^{\mathrm{T}}$ and its closest relatives was carried out by using the BioEdit program (Hall, 1999) and MEGA version 3.1 (Kumar et al., 2004). Phylogenetic reconstruction was inferred by using the maximum-likelihood (Felsenstein, 1981), maximumparsimony (Kluge \& Farris, 1969) and neighbour-joining (Saitou \& Nei, 1987) tree-making algorithms. An evolutionary distance matrix was generated for the neighbour-joining algorithm using the distance model of Jukes \& Cantor (1969) and bootstrap analysis (1000 resamplings).

The 16S rRNA gene sequence of strain $\mathrm{cl}^{\mathrm{T}}$ revealed that the strain belonged to the Betaproteobacteria. The highest similarity was obtained from the comparison with Chitinilyticum aquatile $\mathrm{C}^{\mathrm{T}}{ }^{\mathrm{T}}$ (96.7\% similarity; Chang et al., 2007). Strain $\mathrm{cl}^{\mathrm{T}}$ and Chitinilyticum aquatile $\mathrm{C} 14^{\mathrm{T}}$ were found to form a wellseparated, monophyletic group (Fig. 1). The $16 \mathrm{~S}$ rRNA gene sequence similarity of strain $\mathrm{cl}^{\mathrm{T}}$ to members of all other genera within the Betaproteobacteria was less than $94 \%$, such as Chitinibacter tainanensis $\mathrm{S1}^{\mathrm{T}}$ (93.6\%; Chern et al., 2004), Deefgea rivuli WB $3.4-79^{\mathrm{T}}$ (92.1\%; Stackebrandt et al., 2007), Iodobacter fluviatilis ATCC $33051^{\mathrm{T}}$ (92.1\%; Logan, 1989), Silvimonas terrae $\mathrm{KM}-45^{\mathrm{T}}$ (91.5\%; Yang et al., 2005), Chitinimonas taiwanensis $\mathrm{cf}^{\mathrm{T}}$ (91.3\%; Chang et al., 2004) and Formivibrio citricus DSM $6150^{\mathrm{T}}$ (91.1\%; Hippe et al., 1999). The overall topologies of the phylogenetic trees obtained with the neighbour-joining, maximum-likelihood and maximum-parsimony methods were similar.

Genomic DNA of strain $\mathrm{cl}^{\mathrm{T}}$ was prepared and degraded enzymically into nucleosides as described by Mesbah et al. (1989). The obtained nucleoside mixture was then separated by reversed-phase HPLC equipped with a Cosmosil 5C18 column (Waters). Non-methylated lambda phage DNA (Sigma) was used as the calibration reference. 


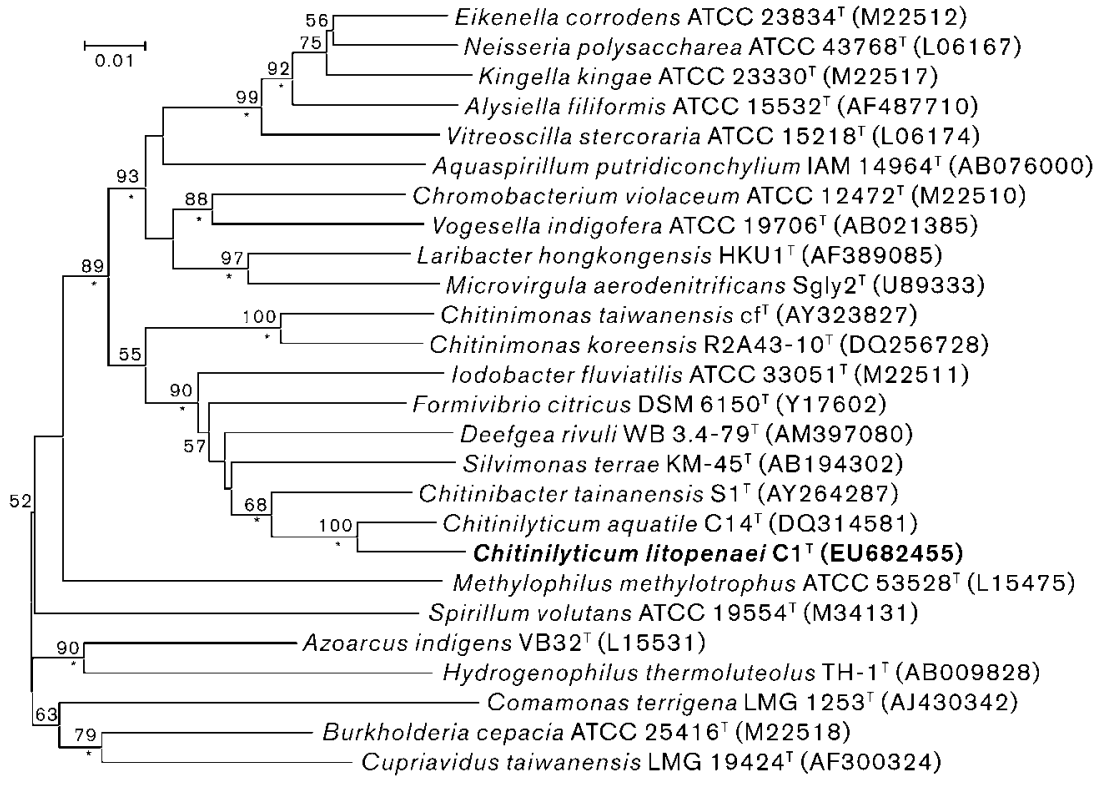

Fig. 1. Neighbour-joining phylogenetic tree of strain $\mathrm{C}^{\top}$ and relatives within the Betaproteobacteria based on 16S rRNA gene sequence comparisons. Bootstrap values (\%) are indicated at branches from 1000 resamplings; only values $>50 \%$ are shown. Asterisks indicate branches of the tree that were also recovered using both the maximumlikelihood and maximum-parsimony tree-making algorithms. GenBank accession numbers are shown in parentheses. Bar, $1 \%$ sequence dissimilarity (1 substitution per 100 nucleotide positions).
Each experiment was conducted in triplicate. The $\mathrm{G}+\mathrm{C}$ content of strain $\mathrm{Cl}^{\mathrm{T}}$ was $62.2 \pm 1.0 \mathrm{~mol} \%$ (mean $\pm \mathrm{SD}$ of triplicate measurements), which is lower than the value reported previously for Chitinilyticum aquatile $\mathrm{C} 14^{\mathrm{T}}$ (69.5 mol\%; Chang et al., 2007).

Fluorometric DNA-DNA hybridization experiments were performed with photobiotin-labelled probes as described by Ezaki et al. (1989). Hybridization was conducted in $50 \%$ formamide at $50{ }^{\circ} \mathrm{C}$. Each experiment was done in triplicate and the values quoted are means \pm SD of triplicate experiments. Strain $\mathrm{Cl}^{\mathrm{T}}$ showed relatively low DNA-DNA binding with its closest phylogenetic neighbours Chitinilyticum aquatile $\mathrm{C} 14^{\mathrm{T}}(38.6 \pm 5.1 \%)$ and Chitinibacter tainanensis $\mathrm{Si}^{\mathrm{T}}(11.0 \pm 3.2 \%)$.

Cellular fatty acid analysis was carried out by the Identification Service of the Bioresource Collection and Research Center (BCRC, Taiwan). Cellular fatty acids were saponified and methylated and then extracted according to the standard protocol of the Microbial Identification System (MIDI, 1999). Fatty acids were separated by GC (Hewlett Packard 6890) and identified by the Microbial Identification software package. The major cellular fatty acids of strain $\mathrm{cl}^{\mathrm{T}}$ were $\mathrm{C}_{16: 0}, \mathrm{C}_{18: 1} \omega 7 c$ and summed feature $3\left(\mathrm{C}_{16: 1} \omega 7 c\right.$ and/ or iso- $\left.\mathrm{C}_{15: 0} 2-\mathrm{OH}\right)$. Detailed fatty acid compositions of strain $\mathrm{cl}^{\mathrm{T}}$ and its close phylogenetic neighbours are shown in Table 1. The fatty acid profile of strain $\mathrm{cl}^{\mathrm{T}}$ was similar to those of Chitinilyticum aquatile $\mathrm{C} 14^{\mathrm{T}}$ and Chitinibacter tainanensis $\mathrm{S}^{\mathrm{T}}$, which both contained predominantly $\mathrm{C}_{16: 0}$, $\mathrm{C}_{18: 1} \omega 7 c$ and summed feature 3 (Table 1 ).

Strain $\mathrm{Cl}^{\mathrm{T}}$ was characterized biochemically by using the Biolog GN2 and API 20NE and API ZYM (bioMérieux) microtest systems according to the manufacturers' instructions. Catalase activity was determined by bubble production in a $10 \%(\mathrm{v} / \mathrm{v}) \mathrm{H}_{2} \mathrm{O}_{2}$ solution. Oxidase activity was
Table 1. Comparison of fatty acid profiles of strain $\mathrm{c} 1^{\top}$ and its phylogenetically closest relatives

Strains: $1, \mathrm{cl}^{\mathrm{T}} ; 2$, Chitinilyticum aquatile $\mathrm{C} 14^{\mathrm{T}}$ (data from Chang et al., 2007); 3, Chitinibacter tainanensis $\mathrm{S}^{\mathrm{T}}$ (Chern et al., 2004). Values are percentages of total fatty acids; -, not detected/not reported. The position of the double bond in unsaturated fatty acids is obtained by counting from the methyl $(\omega)$ end of the molecule.

\begin{tabular}{|lccc|}
\hline Fatty acid & $\mathbf{1}$ & $\mathbf{2}$ & $\mathbf{3}$ \\
\hline $\mathrm{C}_{12: 0}$ & 0.3 & 2.8 & 2.6 \\
$\mathrm{C}_{12: 0} 3-\mathrm{OH}$ & 3.5 & 2.6 & 3.9 \\
$\mathrm{C}_{14: 1} \omega 5 c$ & 0.3 & 0.8 & - \\
$\mathrm{C}_{14: 0}$ & 1.9 & 2.5 & 0.5 \\
$\mathrm{C}_{15: 1} \omega 8 c$ & - & - & 0.3 \\
$\mathrm{C}_{15: 1} \omega 6 c$ & - & - & 0.3 \\
$\mathrm{C}_{15: 0}$ & - & - & 0.8 \\
$\mathrm{C}_{16: 1} \omega 5 c$ & 0.9 & 0.7 & 0.6 \\
$\mathrm{C}_{16: 0}$ & 26.2 & 23.0 & 16.7 \\
$\mathrm{C}_{16: 0} 3-\mathrm{OH}$ & 0.3 & 0.3 & 1.3 \\
$\mathrm{C}_{17: 0}$ cyclo & - & - & 0.3 \\
$\mathrm{C}_{17: 1} \omega 6 c$ & 0.3 & 0.2 & - \\
$\mathrm{C}_{17: 0}$ & - & - & 0.3 \\
$\mathrm{C}_{18: 1} \omega 7 c$ & 24.2 & 23.3 & 19.9 \\
$\mathrm{C}_{18: 1} \omega 5 c$ & - & - & 0.2 \\
$\mathrm{C}_{18: 0}$ & 0.2 & 0.1 & 0.8 \\
$11-$ Methyl $\mathrm{C}_{18: 1} \omega 7 c$ & - & - & 0.1 \\
$10-$ Methyl C $19: 0$ & - & 2.4 & 2.0 \\
$\mathrm{C}_{19: 1} \omega 6 c$ & 0.3 & - & - \\
Summed feature $3 *$ & 41.0 & 41.3 & 48.6 \\
Summed feature $4^{*}$ & 0.2 & - & - \\
& & & \\
\hline
\end{tabular}

${ }^{*}$ Summed feature 3 comprises $\mathrm{C}_{16: 1} \omega 7 c$ and/or iso- $\mathrm{C}_{15: 0}$ 2-OH; summed feature 4 comprises $\mathrm{C}_{14: 0} 3-\mathrm{OH}$ and/or iso- $\mathrm{C}_{16: 1} \mathrm{I}$. 
determined on filter paper moistened with a $1 \%(\mathrm{w} / \mathrm{v})$ aqueous solution of $N, N, N^{\prime}, N^{\prime}$-tetramethyl-p-phenylenediamine. Strain $\mathrm{cl}^{\mathrm{T}}$ was also examined for a broad range of phenotypic properties using conventional methods (MacFaddin, 2000). Susceptibility to antimicrobial agents was determined by the disc diffusion assay. A cell suspension was diluted in sterile saline (to 0.5 McFarland) after reaching the exponential growth phase and then spread onto CB medium and incubated at $35{ }^{\circ} \mathrm{C}$. Antimicrobial discs (Difco) used in this experiment separately contained amikacin $(30 \mu \mathrm{g})$, ampicillin $(10 \mu \mathrm{g})$, chloramphenicol $(30 \mu \mathrm{g})$, erythromycin $(15 \mu \mathrm{g})$, gentamicin $(10 \mu \mathrm{g})$, kanamycin $(30 \mu \mathrm{g})$, nalidixic acid $(30 \mu \mathrm{g})$, novobiocin $(30 \mu \mathrm{g})$, rifampicin $(5 \mu \mathrm{g})$, penicillin $\mathrm{G}(10 \mathrm{U})$, streptomycin $(10 \mu \mathrm{g})$ and tetracycline $(30 \mu \mathrm{g})$. The effect of antibiotics on cell growth was assessed after 3 days of incubation at $35{ }^{\circ} \mathrm{C}$ and susceptibility was scored based on the distance from the edge of the clear zone to that of the disc. If the distance was greater than $3 \mathrm{~mm}, 1-$ $3 \mathrm{~mm}$ or less than $1 \mathrm{~mm}$, the strain was respectively classified as susceptible, moderately susceptible or resistant.

Differences in phenotypic and biochemical characteristics between strain $\mathrm{cl}^{\mathrm{T}}$ and related phylogenetic neighbours are summarized in Table 2. Strain $\mathrm{cl}^{\mathrm{T}}$ can be distinguished clearly from Chitinilyticum aquatile $\mathrm{C} 14^{\mathrm{T}}$ by the absence of oxidase, glucose fermentation, gelatin hydrolysis and $\beta$ galactosidase. Different phenotypic characteristics between strain $\mathrm{Cl}^{\mathrm{T}}$ and Chitinibacter tainanensis $\mathrm{S1}^{\mathrm{T}}$ include oxygen requirement, oxidase, nitrate reduction, red pigment production and assimilation of mannose.

Strain $\mathrm{cl}^{\mathrm{T}}$ probably represents a novel species belonging to the genus Chitinilyticum, since the 16S rRNA gene sequence similarity to the closest relative with a validly published name, Chitinilyticum aquatile $\mathrm{C} 14^{\mathrm{T}}$, is $96.7 \%$. Moreover, strain $\mathrm{cl}^{\mathrm{T}}$ was readily distinguished from its nearest phylogenetic neighbours, Chitinilyticum aquatile $\mathrm{C} 14^{\mathrm{T}}$ and Chitinibacter tainanensis $\mathrm{S}^{\mathrm{T}}$, by phenotypic and biochemical characteristics (Table 2). Therefore, based on phenotypic and phylogenetic criteria, we suggest that strain $\mathrm{cl}^{\mathrm{T}}$ should be assigned to a novel species, for which the name Chitinilyticum litopenaei sp. nov. is proposed. We also present an emended description of the genus Chitinilyticum to take into account the properties of strain $\mathrm{cl}^{\mathrm{T}}$.

\section{Emended description of the genus Chitinilyticum Chang et al. 2007}

The description of the genus Chitinilyticum (Chang et al., 2007 ) is emended as follows. Oxidase activity is variable for different species. The DNA G+C content is 62.2$69.5 \mathrm{~mol} \%$.

\section{Description of Chitinilyticum litopenaei sp. nov.}

Chitinilyticum litopenaei (li.to.pen.ae'i. N.L. n. Litopenaeus the scientific name of a genus of shrimp; N.L. gen. n. litopenaei of Litopenaeus, referring to the isolation of the
Table 2. Differentiating characteristics between strain $\mathrm{c1}^{\top}$ and its phylogenetically closest relatives

Strains: $1, \mathrm{c1}^{\mathrm{T}} ; 2$, Chitinilyticum aquatile $\mathrm{C} 14^{\mathrm{T}} ; 3$, Chitinibacter tainanensis $\mathrm{S}^{\mathrm{T}}$. Results were acquired in the present study with the exception of DNA G $+\mathrm{C}$ contents for Chitinilyticum aquatile $\mathrm{C} 14^{\mathrm{T}}$ and Chitinibacter tainanensis $\mathrm{S1}^{\mathrm{T}}$, which were respectively obtained from Chang et al. (2007) and Chern et al. (2004).

\begin{tabular}{|lccc|}
\hline Characteristic & $\mathbf{1}$ & $\mathbf{2}$ & $\mathbf{3}$ \\
\hline Source & Fresh water & Fresh water & Soil \\
$\mathrm{O}_{2}$ requirement & FAN & FAN & SA \\
Red pigment production & - & - & + \\
Oxidase & - & + & + \\
API 20NE tests & & & \\
Nitrate reduction & + & + & - \\
Glucose fermentation & - & + & - \\
Gelatin hydrolysis & - & + & - \\
Assimilation of mannose & + & + & - \\
Oxidation of (Biolog GN2): & & & \\
Acetic acid & - & + & - \\
DL-Lactic acid & - & + & - \\
$\alpha$-Hydroxybutyric acid & - & + & - \\
D-Gluconic acid & - & + & + \\
L-Asparagine & - & + & - \\
L-Aspartic acid & - & + & - \\
L-Glutamic acid & - & + & - \\
Maltose & + & - & - \\
Sucrose & - & + & - \\
D-Fructose & + & + & - \\
Trehalose & + & + & - \\
DNA G+C content (mol\%) & 62.2 & 69.5 & 56 \\
& & & \\
\hline
\end{tabular}

${ }^{\star}$ FAN, Facultatively anaerobic; SA, strictly aerobic.

type strain from a culture pond for Pacific white shrimp, Litopenaeus vannamei).

Cells are Gram-negative rods, 3.0-4.5 $\mu \mathrm{m}$ long and $0.3-$ $0.5 \mu \mathrm{m}$ in diameter. They occur singly and are motile by single polar flagella. Poly- $\beta$-hydroxybutyrate granules are present. Endospores are not formed. Colonies on CB medium are surrounded by a large clear zone, derived from degradation of chitin. Grows well by using chitin as the sole carbon, nitrogen and energy source under both aerobic and anaerobic conditions. No diffusible pigments are produced. Growth occurs at $15-40{ }^{\circ} \mathrm{C}, \mathrm{pH} 7.0-11.0$ and $0-0.75 \%$ $\mathrm{NaCl}$. Positive for catalase but negative for oxidase activity. API 20NE tests show positive reactions for nitrate reduction, assimilation of mannose, $\mathrm{N}$-acetyl-D-glucosamine and gluconate and negative reactions for glucose fermentation and gelatin hydrolysis, indole production, arginine dihydrolase, urease, aesculin hydrolysis, $\beta$-galactosidase and assimilation of arabinose, mannitol, maltose, caprate, adipate, malate, citrate and phenylacetate. In API ZYM tests, shows positive reactions for alkaline phosphatase, C4 esterase, leucine arylamidase, acid phosphatase, naphtholAS-BI-phosphohydrolase and $N$-acetyl- $\beta$-glucosaminidase 
and negative reactions for $\alpha$-glucosidase, $\beta$-glucuronidase, $\alpha$ galactosidase, $\beta$-galactosidase, $\beta$-glucosidase, $\mathrm{C} 14$ lipase, valine arylamidase, cystine arylamidase, C8 lipase, $\alpha$ mannosidase, $\alpha$-fucosidase, trypsin and $\alpha$-chymotrypsin. The following carbon sources are oxidized (positive in the Biolog GN2 system): dextrin, glucose, D-fructose, glycogen, maltose, sucrose, cellobiose, mannose, trehalose, turanose, $\mathrm{N}$-acetyl-D-glucosamine, methyl pyruvate and gentiobiose. The following substrates are not oxidized (negative in the Biolog GN2 system): gluconate, D-glucuronic acid, acetic acid, $\alpha$-ketobutyric acid, $\alpha$-ketovaleric acid, DL-lactate, $\alpha$ hydroxybutyric acid, glucose 6-phosphate, $\alpha$-cyclodextrin, Tweens 40 and 80, arabinose, lactulose, psicose, melibiose, itaconic acid, L-fucose, inosine, $\alpha$-lactose, D-galactose, raffinose, L-rhamnose, mannitol, xylitol, glycerol, arabitol, i-erythritol, D-galacturonic acid, D-sorbitol, myo-inositol, adonitol, 2,3-butanediol, $N$-acetyl-D-galactosamine, DL- $\alpha$ glycerol phosphate, glucose 1-phosphate, methyl $\beta$-Dglucoside, 2-aminoethanol, monomethyl succinate, citrate, formic acid, D-galactonic acid lactone, malonic acid, $\alpha$ ketoglutaric acid, propionic acid, urocanic acid, D-saccharic acid, succinic acid, bromosuccinic acid, succinamic acid, $p$ hydroxyphenylacetic acid, cis-aconitic acid, quinic acid, sebacic acid, $\gamma$-aminobutyric acid, $\beta$ - and $\gamma$-hydroxybutyric acids, D-glucosaminic acid, phenylethylamine, L-glutamic acid, L-histidine, L-aspartic acid, L-leucine, L-threonine, Lphenylalanine, L-asparagine, L- and D-alanine, L- and Dserine, L-proline, hydroxy-L-proline, glycyl L-glutamic acid, L-ornithine, DL-carnitine, L-pyroglutamic acid, glycyl Laspartic acid, L-alanyl glycine, putrescine, alaninamide, glucuronamide, thymidine and uridine. Sensitive to amikacin $(30 \mu \mathrm{g})$, ampicillin $(10 \mu \mathrm{g})$, chloramphenicol $(30 \mu \mathrm{g})$, kanamycin $(30 \mu \mathrm{g})$, nalidixic acid $(30 \mu \mathrm{g})$, novobiocin $(30 \mu \mathrm{g})$, rifampicin $(5 \mu \mathrm{g})$ and tetracycline $(30 \mu \mathrm{g})$. Resistant to erythromycin $(15 \mu \mathrm{g})$, gentamicin $(10 \mu \mathrm{g})$, penicillin $\mathrm{G}(10 \mathrm{U})$ and streptomycin $(10 \mu \mathrm{g})$. The major fatty acid components are $\mathrm{C}_{16: 0}, \mathrm{C}_{18: 1} \omega 7 c$ and summed feature $3\left(\mathrm{C}_{16: 1} \omega 7 c\right.$ and/or iso- $\left.\mathrm{C}_{15: 0} 2-\mathrm{OH}\right)$. The DNA $\mathrm{G}+\mathrm{C}$ content of the type strain is $62.2 \mathrm{~mol} \%$.

The type strain, $\mathrm{cl}^{\mathrm{T}}\left(=\mathrm{BCRC} 17609^{\mathrm{T}}=\mathrm{DSM} 21440^{\mathrm{T}}\right)$, was isolated from surface water of an aquaculture pond containing Pacific white shrimp (Litopenaeus vannamei) at Pingtung in southern Taiwan.

\section{References}

Chang, S. C., Wang, J. T., Vandamme, P., Hwang, J. H., Chang, P. S. \& Chen, W. M. (2004). Chitinimonas taiwanensis gen. nov., sp. nov., a novel chitinolytic bacterium isolated from a freshwater pond for shrimp culture. Syst Appl Microbiol 27, 43-49.

Chang, S. C., Chen, W. M., Wang, J. T. \& Wu, M. C. (2007). Chitinilyticum aquatilis gen. nov., sp. nov., a novel chitinolytic bacterium isolated from a freshwater pond for Pacific white shrimp culture. Int J Syst Evol Microbiol 57, 2854-2860.

Chen, W. M., Laevens, S., Lee, T. M., Coenye, T., De Vos, P., Mergeay, M. \& Vandamme, P. (2001). Ralstonia taiwanensis sp. nov., isolated from root nodules of Mimosa species and sputum of a cystic fibrosis patient. Int J Syst Evol Microbiol 51, 1729-1735.
Chern, L. L., Stackebrandt, E., Lee, S. F., Lee, F. L., Chen, J. K. \& Fu, H. M. (2004). Chitinibacter tainanensis gen. nov., sp. nov., a chitindegrading aerobe from soil in Taiwan. Int J Syst Evol Microbiol 54, 1387-1391.

Chun, J., Lee, J.-H., Jung, Y., Kim, M., Kim, S., Kim, B. K. \& Lim, Y. W. (2007). EzTaxon: a web-based tool for the identification of prokaryotes based on $16 \mathrm{~S}$ ribosomal RNA gene sequence. Int J Syst Evol Microbiol 57, 2259-2261.

Ezaki, T., Hashimoto, Y. \& Yabuuchi, E. (1989). Fluorometric deoxyribonucleic acid-deoxyribonucleic acid hybridization in microdilution wells as an alternative to membrane filter hybridization in which radioisotopes are used to determine genetic relatedness among bacterial strains. Int J Syst Bacteriol 39, 224-229.

Felsenstein, J. (1981). Evolutionary trees from DNA sequences: a maximum likelihood approach. J Mol Evol 17, 368-376.

GCG (1995). Wisconsin Package Version 8.1 Program Manual. Madison, WI: Genetics Computer Group.

Gooday, G. W. (1990). The ecology of chitin degradation. Adv Microb Ecol 11, 387-430.

Hall, T. A. (1999). BioEdit: a user-friendly biological sequence alignment editor and analysis program for Windows 95/98/NT. Nucleic Acids Symp Ser 41, 95-98.

Hippe, H., Hagelstein, A., Kramer, I., Swiderski, J. \& Stackebrandt, E. (1999). Phylogenetic analysis of Formivibrio citricus, Propionivibrio dicarboxylicus, Anaerobiospirillum thomasii, Succinimonas amylolytica and Succinivibrio dextrinosolvens and proposal of Succinivibrionaceae fam. nov. Int J Syst Bacteriol 49, 779-782.

Jukes, T. H. \& Cantor, C. R. (1969). Evolution of protein molecules. In Mammalian Protein Metabolism, vol. 3, pp. 21-132. Edited by H. N. Munro. New York: Academic Press.

Kluge, A. G. \& Farris, F. S. (1969). Quantitative phyletics and the evolution of anurans. Syst Zool 18, 1-32.

Kumar, S., Tamura, K. \& Nei, M. (2004). MEGA3: integrated software for molecular evolutionary genetics analysis and sequence alignment. Brief Bioinform 5, 150-163.

Logan, N. A. (1989). Numerical taxonomy of violet-pigmented, gramnegative bacteria and description of Iodobacter fluviatile gen. nov., comb. nov. Int J Syst Bacteriol 39, 450-456.

MacFaddin, J. F. (2000). Biochemical Tests for the Identification of Medical Bacteria, 3rd edn. Baltimore: Williams \& Wilkins.

Mesbah, M., Premachandran, U. \& Whitman, W. B. (1989). Precise measurement of the $\mathrm{G}+\mathrm{C}$ content of deoxyribonucleic acid by highperformance liquid chromatography. Int J Syst Bacteriol 39, 159-167.

MIDI (1999). Sherlock Microbial Identification System, Operating Manual, version 3.0. Newark, DE: MIDI, Inc.

Powers, E. M. (1995). Efficacy of the Ryu nonstaining $\mathrm{KOH}$ technique for rapidly determining gram reactions of food-borne and waterborne bacteria and yeasts. Appl Environ Microbiol 61, 3756-3758.

Saitou, N. \& Nei, M. (1987). The neighbor-joining method: a new method for reconstructing phylogenetic trees. Mol Biol Evol 4, 406-425.

Shigemasa, Y. \& Minami, S. (1996). Applications of chitin and chitosan for biomaterials. Biotechnol Genet Eng Rev 13, 383-420.

Stackebrandt, E., Lang, E., Cousin, S., Päuker, O., Brambilla, E., Kroppenstedt, R. \& Lünsdorf, H. (2007). Deefgea rivuli gen. nov., sp. nov., a member of the class Betaproteobacteria. Int J Syst Evol Microbiol 57, 639-645.

Yang, H.-C., Im, W.-T., An, D.-S., Park, W.-S., Kim, I. S. \& Lee, S.-T. (2005). Silvimonas terrae gen. nov., sp. nov., a novel chitin-degrading facultative anaerobe belonging to the 'Betaproteobacteria'. Int J Syst Evol Microbiol 55, 2329-2332. 